\title{
Radical Detection on Student Knowledge Using Classification Supervised Learning Method
}

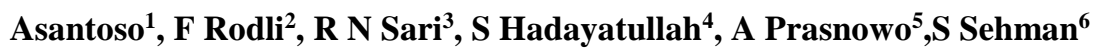 \\ \{rektor@umaha.ac.id ${ }^{1}$, agung@dosen.umaha.ac.id ${ }^{5}$, rispro@umaha.ac.id ${ }^{3}$ \} \\ 1,2,3,4,5,6Universitas Maarif Hasyim Latif SidoarjoJl. Raya Megare Sepanjang - Sidoarjo Jawa \\ Timur, Indonesia
}

\begin{abstract}
The soft computing used to detect radicalism is the Great Game which contains humanity's psychology programming modules. The output in the form of game assessment are points obtained on contents as a table with the number in column and rows. Machine learning also used for data processing that utilizes SVM method. System performance consists of: learning data to find the nationalism class, training process to find the radicalism class, testing data process using test data already trained and the final process is testing data process using test data before trained. The SVM process results in the form of graphs and information that will be used to recommend whether including nationalism or radicalism.
\end{abstract}

Keyword:Great Game, Radical Knowledge, Machine Learning and System Performance

\section{Introduction}

After the reform of the student, movement map has changed, Cipayung group which previously considered to dominate the Islamic movement on campus, now shifted by other groups and some student organizations one of the Indonesian Muslim Student Action Union which is an extension of the Muslim Brotherhood. The group is considered to have an ideological relationship with the Ikhwanul Muslimin international radical group. This group is more ideological radicalism with the ideals of establishing their own version of an Islamic state that tends to be confious to the madhhab and monolithic comparison so that the potential for ideological radicalization (Anas Saidi, 2016). According to a survey 25 percent of students and 21 percent of lecturers said Pancasila is no longer relevant. While 84.8 percent of students and 76.2 percent of lecturers agreed with the implementation of Islamic Shari'a. While in last year's survey, four percent of Indonesians approved the militant group of the Islamic State of Iraq and Syria (ISIS). They are between 19-25 years old. While 5 percent of them are students.

Radicalism in college does not appear significantly in the form of student activities, but is another form, so the potential can't be detected early. However, the behavior of radicalism can be detected through student's personality. Therefore required a method that can detect the personality of the students by doing approach in everyday life. The researcher proposed a model of radical discipline detection in the form of student as a software of Game. 


\section{Literature Review}

\subsection{Radicalism}

According to the latest theories in the study of social and political science, the ideological criticism and discourse analysis that radicalism is understood as a social and political were born in a condition of dislocation or crisis and permanent in society [1]. Radicalism is assumed to arise because of the strengthening of injustice and unfairness organized by dominant groups in politics and economics. the concept shows the human political agency for improvement and change. A person or a group is called a radical not only because it is aware of domination but also actively pursues ideological and social change[2].

Democratic-inclusive radicalism uses inclusive and participatory logic through collective action to make changes or negotiate politically with the dominant forces in society and the state. While intolerant-exclusive radicalism uses the logic of withdrawal from coexistence in the face of dislocation or crisis and is driven by an exclusive ideology, but because of the relative outcomes of the negotiating processes which do not allow their identity and interests to be accommodated in the general norms of society or constitution in The life of a country. The, unlike negotiation process, results in the accommodation of their identities and interests in general or constitutional norms, the greater the likelihood of using violence as the articulation and means of achieving their moral and political objectives.

Thus religious radicalism is a philosophy that refers to the beliefs of a particular group, who desire and make changes to religious values that are considered contrary to their understanding. This is done by tearing down existing systems and structures to their roots quickly over subjective considerations [3].

The results of research from the Jakarta Institute of Islamic Studies and Peace is surprising. Research conducted between October 2010 to 2015 against teachers of Islamic Education and students (junior high and senior high school) in Jabodetabek shows that $49 \%$ of students agree with the action of radicalism for the religion of public college campus, student tendency to support the action of radicalism is also very high. This is revealed in a study on Islamic Campus involving 2466 samples of students from various leading universities in Indonesia. When the students were asked about the implementation of "amar makruf nahi munkar" in the form of sweeping places that are considered immoral sources, they answered as follows: about $65 \%$ (594 respondents) support sweeping disobedience, $8 \%$ (446 respondents) support as well as actively participate in activities Sweeping. About\% (268 respondents) said they did not support sweeping, and the rest, 6\% (58 respondents) did not give the answer. Furthermore, those who support sweeping argue that such sweeping activities as part of religious orders $(88 \%)$, support sweeping because of the opinion that the security forces are unable to enforce the law (4\%), and for reasons of moral decadence (8\%)[4].

\subsection{Data Mining}

Data mining is a process to find patterns and trends of data warehouse. The purpose of this process is to compile large amounts of data to get new information. Data mining also has a sense of exploration and analysis of data automatically or semi-automatic from large amounts of data to obtain meaningful patterns and rules for users[5].

Data Mining is a process of searching patterns and hidden relationships in large amounts of data with the aim of classifying, estimating, forecasting, association rules, sequential patterns, clustering, regression, descriptions, and visualizations[6]. Data mining can assist in taking actions by providing knowledge of patterns derived from past data[7]. 
The process in the data mining stage consists of three steps including[8]:

A. Data Preparation

In this step, data is selected, cleaned, and performed preprocessed following the guidelines and knowledge of domain experts who capture and integrate internal and external data into organizational reviews overall.

\section{B. Data mining algorithm}

The use of data mining algorithms is done in this step to digging up the integrated data to facilitate the identification of valuable information.

\section{Data analysis phase}

Outputs from data mining are evaluated to see if the knowledge domain is found in the form of a rule that has been extracted from the network.

Data mining technology can be divided between traditional and fine technology. Statistical analysis is representative of traditional technology. As for fine data mining techniques are all kinds of artificial intelligence used, which are more commonly used are decision tree species, neural networks, genetic algorithms, fuzzy logic and induction rules. The use of different types of applications can often lead to different results [8].

\subsection{Support Vector Machine (SVM)}

The SVM concept according to[9] can be explained simply as a search for the best hyperplane that serves as a separator of two classes in the input space. Support Vector Machine characteristics as follows:

1 In principle, SVM is a linear classifier

2 Pattern recognition is done by transforming the data on the input space to a higher space dimension, and the optimization is done in the new vector space. This distinguishes SVM from typical pattern recognition solutions, which optimize the parameters in the resulting transformation space that is lower than the input space dimension.

3 Applying the strategy of Structural Risk Minimization (SRM)

4 The working principle of SVM is basically only capable of handling the classification of two classes.

Support Vector Machine (SVM) is proposed as an alternative to standard SVM that has proven to be more efficient than traditional SVM in scalable data processing[10]. Classification is a data mining task that predicts groupings for data cases. In the educational application of the classification method. An example is to classify the student's work, its predicate and its final value [11].

The concept of SVM can be explained simply as an attempt to find the best hyperplane that serves as a separator of two classes in the input space. The pattern consists of two classes: +1 and -1 , belonging to class -1 symbolized in red (box), while pattern in class +1 , symbolized by yellow (circle). Classification problems can be translated by finding the line (hyperplane) that separates the two groups. Various alternate lines of discrimination (discrimination boundaries)

In this study the authors are interested to apply the Support Vector Machine (SVM) classification method to detect radical ideology among students. The analyst steps according to [12] are as follows

1. Collecting secondary data. 
2. Conduct classification predictions.

a. Enter data according to MATLAB software format.

b. Divide data into training data and data testing.

c. Determining the method of hyperplane approach SVM Multikelas that is with SVM method Multikelas one opponent all (SLA)

d. Specifies the kernel function to be used as an SVM SLA hyperplane modeling.

e. Specifies the parameter value of $\mathrm{C}$ and the kernel parameter values to be used as the SVM SLA hyperplane modeling.

f. Getting alpha values and $b$

g. Form three hyperplane equations

h. Make predictions of classification

3. Evaluate the performance of the classification model using the confusion matrix.

a) Calculates the predicted classification accuracy

b) Select the best parameters and kernel function values

\section{Research Methods}

The research data used is taken from the Outstanding Game game output. Game players are actually involuntarily made the object of research because the game output is not only personality information but also in the form of scoring numbers on how to think, how to behave, how to argue.

\subsection{GretaeGame}

Identify game users by means of students are required to download their own on the web that has been provided but previously had to Login first. Because later the Game content will be unified with the campus web so that anyone who downloads will leave the identity of the NIM (Student Number). So that can use UMAHA Students only.

After the students download the Game to play then the student must first install. For easy and precise choice and vital speed in playing Game Student is guided every step of the game in the form of sound. The picture below shows a radical detection path that must be played by the students themselves. 


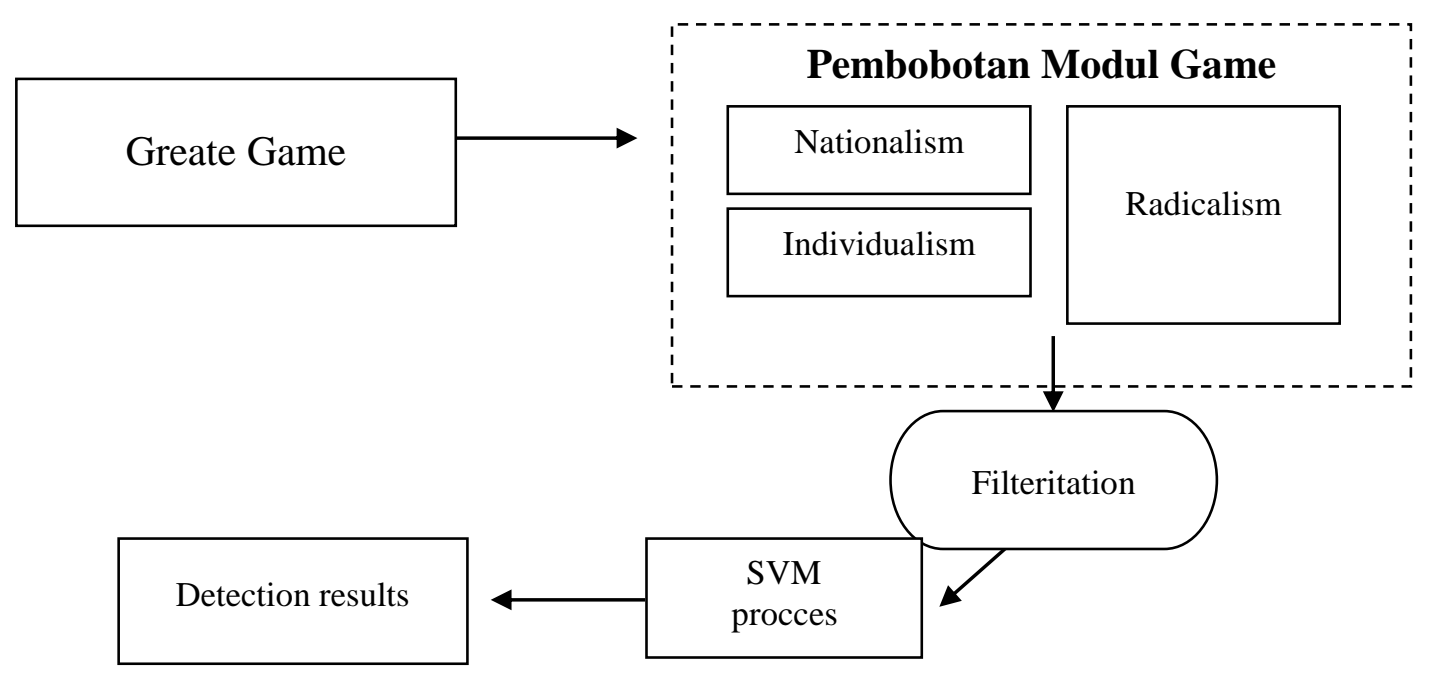

Figure 1: Great Game Diagram

The research flow of personality identification from the side of Psychology that is based on daily life. The models include how to socialize, how to dress, color, fun. In order for the results to be achieved maximally then the game disguised only if a simulation for personality identification only. First of all the student must play Great Game until finished and will appear a self-information personality. The real output of the game in the form of assessment figures consisted of Nationalism, Individualism, and Terrorism. Because in this study aims to detect radical ideology in the students then the data taken only the data of Nationalism and Radicalism. Then the two data is processed in machine learning by using Support Vector Machine (SVM). The result of the decision is whether the students belong to nationalism or radicalism.

\subsection{Research Data}

The research data used is taken randomly from students of Maarif University Hasyim Latif on Faculty of Engineering ie from Industrial Engineering, Mechanical Engineering, Informatics Engineering, Computer Engineering, and Visual Communication Design. The following table is the raw data of Outstanding Game output that has been played by the students.

\begin{tabular}{cccc}
\hline NIM & Nasionalisme & Individualisme & Radikalisme \\
\hline 141216113 & 32 & 3 & 5 \\
\hline 141216176 & 23 & 10 & 7 \\
\hline 141216197 & 21 & 3 & 4 \\
\hline 141216109 & 29 & 9 & 2 \\
\hline 141216154 & 32 & 2 & 5 \\
\hline 142215512 & 20 & 7 & 6 \\
\hline 142215507 & 29 & 2 & 5 \\
\hline 142215595 & 21 & 6 & 6 \\
\hline
\end{tabular}




\begin{tabular}{cccc}
\hline 142215513 & 16 & 4 & 5 \\
\hline 142215565 & 17 & 6 & 2 \\
\hline 143217529 & 30 & 6 & 4 \\
\hline 143217537 & 35 & 4 & 1 \\
\hline 143217545 & 15 & 25 & 0 \\
\hline 143217514 & 8 & 10 & 22 \\
\hline 143217565 & 25 & 9 & 5 \\
\hline 131216132 & 18 & 4 & 4 \\
\hline 131216137 & 21 & 7 & 8 \\
\hline 131216138 & 22 & 9 & 3 \\
\hline 131216139 & 16 & 8 & 4 \\
\hline 131216140 & 23 & 8 & 2 \\
\hline 144215503 & 20 & 15 & 9 \\
\hline 144215504 & 21 & 6 & 30 \\
\hline 144215501 & 4 & 6 & 9 \\
\hline 144215511 & 1 & 30 & 8 \\
\hline 144215518 & 19 & 10 & \\
\hline
\end{tabular}

Table 1: Grate Game Playing Results

The purpose of this study is to detect students who are radical, but a plural class of data that consists of nationalism, individualism, and radicalism. Because of the class that is used only 2 (two) class that is class of Nationalism and Terrorism class.

\section{Discussion}

According to Wikipedia machine learning (machine learning) or machine learning is the science branch of artificial intelligence (artificial intelligence) who learn how to learn from data. In the manufacture of learning machines by utilizing the method of support vector machine (SVM) because the method is very popular today. [13]system performance design is performed in 4 steps in the following sequence of processes:

1. First process: training data for False class. The data used are taken from nationalism class data.

2. The second process: training data for True class. The data in this class is data sourced from Terrorism class.

3. The third process: testing using test data already trained. 


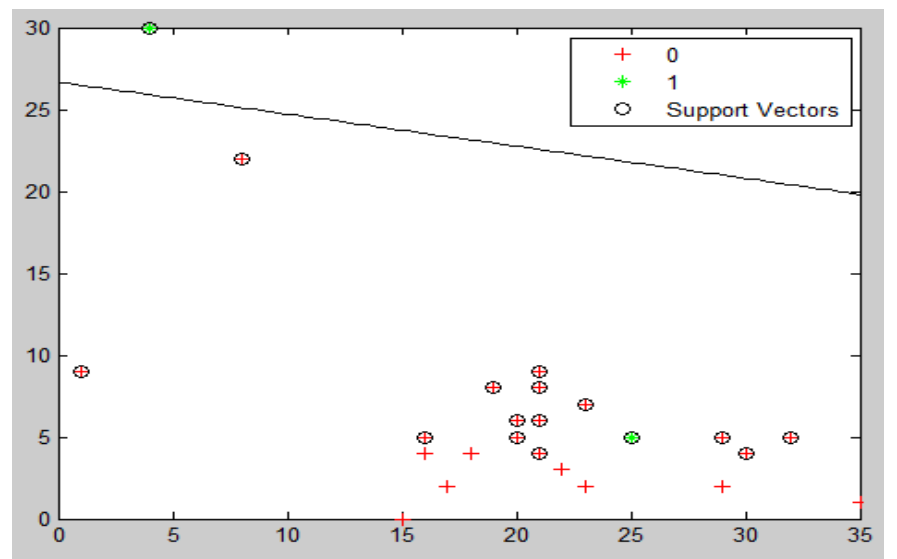

Figure 2 : Result Testing Data has Learned

The research data used is taken from the game output Great Game is the data ever done previous training. Shown in Figure 2 is a graphic view, a line of separation or a hyperplane that separates the two classes of Nationalism and Radicalism. Inside the graph contains 2 pieces of pattern (plus image) representing each data that has been done training. The red pattern represents the class of Nasinalism, the light green color representing the class of Radicalism. So can be said blue color is test data Radicalism and color pink is test data of Nationalism. Another one is a small sphere, the sphere can be light green and the red circle is Support Vector. The SVM concept is explained simply as an attempt to separate train data and test data with hyperplane. Margin is the distance between the hyperplane and the nearest data of each class.

1. The fourth process: testing using test data that has not been studied. The most fundamental difference of this test is that the data used has never been practiced at all

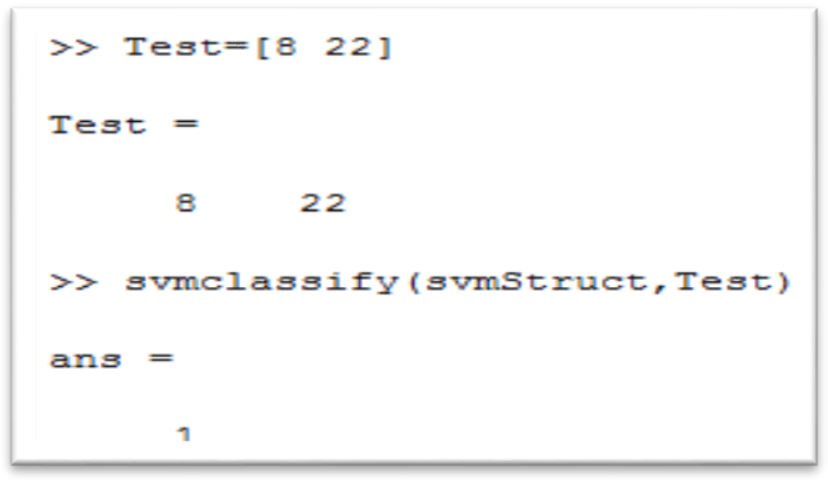

Figure 3: Result Testing Data Not Learning

Figure 3 is the result of direct execution of MatLab Application which will be tested with a class of Nationalism and class of Radicalism. Because testing with data that has never done 
previous training then the result is just output in the form of answer number $=0$ and number $=$ 1. This means that if the results of the number 1 then it can be said the test results of students said to understand Radicalism and vice versa if the number of students then understand Nationalism.

\section{Conclusion}

Based on the experimental results using research data that had been done before training and data that has not been done training or direct testing of decision making recommendations using the SVM method successfully detect Radical ideology. However testing is still not comprehensive for other Faculty which consists of Faculty of Economics, Faculty of Law and Faculty of Health. Because the study program at UMAHA there are 11 then it can be said still less 6 study programs again. To measure how great the Game Great accuracy population of respondents should be more distribution also needs to be done outside the campus of UMAHA.

\section{References}

[1] M. Sugiono, E. Hiariej, F. F. Djalong, and L. Hakim, "Rekonseptualisasi: Terorisme, Radikalisme dan Kekerasan," 2011.

[2] N. Burhanuddin, "Akar dan Motif Fundamentalisme Islam: Reformulasi Tipologi Fundamentalisme dan Prospeknya di Indonesia," Wawasan J. Ilm. Agama dan Sos. Budaya, vol. 1, no. 2, pp. 199-210, Nov. 2016.

[3] N. Syam, Radikalisme dan Masa Depan Agama;Rekontruksi Tafsir Sosial Agama. Surabaya: IAIN Press, 2001.

[4] A. Fadjar, Laporan Penelitian Islam Kampus. Jakarta: Ditjen Dikti Depdiknas, 2007.

[5] U. Fayyad, G. Piatetsky-Shapiro, and P. Smyth, "The KDD process for extracting useful knowledge from volumes of data.," Commun. ACM, vol. 39, no. 11, 1996.

[6] R. R. R. Fiska, "Penerapan Teknik Data Mining dengan Metode Support Vector Machine (SVM) untuk Memprediksi Siswa yang Berpeluang Drop Out (Studi Kasus di SMKN 1 Sutera)," Jar. Sist. Inf. Robot., vol. 1, no. 1, pp. 42-51, 2017.

[7] A. Santoso, Penggalian Kaidah Multilevel Association Rule dari Data Mart Swalayan ASGAP Krian, Seminar Nasional "Inovasi dalam Desain dan Teknologi. IDeaTech, 2015.

[8] E. Miranda, "Implementasi Data Warehouse Dan Data Mining: Studi Kasus Analisis Peminatan Studi Siswa," ComTech, vol. 2, no. 1, 2011.

[9] A. S. Nugroho, A. B. Witarto, and D. Handoko, "Support vector machine teori dan aplikasinya dalam bioinformatika.," Kuliah Umum Ilmu Komputer. com., 2003.

[10] C.-H. Huang, Y. Keng-CHieh, and H.-Y. Kao, "Analyzing Big Data With The Hybrid Interval Regression Methods," ATIN Sains dan Teknol. Inf. J., vol. 3, no. 1, 2014.

[11] S. Sembiring, U. Khoir, and I. Lubis, Predictor Model in Prediction of Student Performance using Decision Tree and Smooth Support Vector Machine. Medan: Sekolah Tinggi Harapan Medan, 2011.

[12] P. A. Octaviani, Y. Wilandari, and D. Ispriyanti, "Penerapan Metode Klasifikasi Support Vector Machine (Svm) Pada Data Akreditasi Sekolah Dasar (Sd) Di Kabupaten Magelang," J. GAUSSIAN, vol. 3, no. 4, 2014.

[13] A. Santoso, I. Arif, and M. Hatta, "Pembelajaran Supervised SVM Untuk Identifikasi Obyek Pisau Pada Mesin X-Ray Bandara Juanda," Nusant. J. Comput. its Appl., vol. 1, no. $1,2017$. 
